\title{
The Effectiveness of the Fed's Quantitative Easing Policy - A Survey of the Econometrics
}

\author{
ANSGAR BELKE \\ University of Duisburg-Essen, Faculty of Business Administration and Economics, Universitätsstraße, \\ 2, 45141 Essen, Germany.E-mail: ansgar.belke@uni-due.de
}

\begin{abstract}
If one is concerned with the effects of zero interest rate policy, it is obvious to ask about the success of unconventional monetary policy in the form of "Quantitative Easing" (QE). The success is usually measured by advocates of these measures by the induced extent of the interest rate reduction in the long run (the short-term interest rate is already zero at the time of the introduction of QE) or an increase in inflation expectations. Damaging side effects are partly accepted implicitly, but not always explicitly offset. While numerous empirical studies have long been concerned with the national effects of QE, the empirical evidence regarding the international effects of these monetary policy measures is growing steadily. This paper critically assesses different angles of this research and concludes that searching for structural breaks in cointegration relationships among international long-term interest rates and some macroeconomic fundamentals is the way to go.
\end{abstract}

Keywords: Quantitative Easing, Event Studies, Unconventional Monetary Policy, Time Series Econometrics, Cointegrated VAR, Recursive Methods.

\section{La efectividad de expansión cuantitativa de la Fed. Una panorámica econométrica}

\begin{abstract}
RESUMEN
El interés por los efectos de la política de tipos nulos implica de inmediato preguntarse por el éxito de la política monetaria no convencional en forma de expansión (o flexibilización) cuantitativa. Los defensores de este tipo de medidas suelen medir dicho éxito por el montante inducido en la reducción del tipo de interés a largo plazo (el tipo a corto ya es cero en el momento de la implantación de la expansión cuantitativa) o por el incremento en las expectativas de inflación. Se aceptan, en parte, implícitamente, efectos secundarios negativos, pero no siempre se compensan explícitamente. Aunque han sido numerosos los estudios empíricos que han abordado la cuestión de la expansión cuantitativa a escala nacional, la evidencia empírica sobre los efectos internacionales de este tipo de política monetaria está creciendo constantemente. Este artículo evalúa, de una forma crítica, los diferentes ángulos de dicha investigación y concluye que la búsqueda de cambios estructurales en relaciones de cointegración entre tipos de interés internacionales a largo plazo y algunos fundamentales macroeconómicos es el camino a seguir.
\end{abstract}

Palabras clave: Expansión cuantitativa, estudios de caso, política monetaria no convencional, econometría de series temporales, VAR cointegrado, métodos recursivos.

JEL Classification: E58, F42, G15

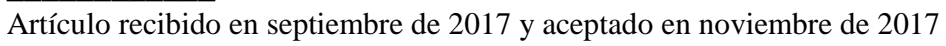

Artículo disponible en versión electrónica en la página www.revista-eea.net, ref. ə-36108 


\section{MOTIVATION}

Massive negative shocks triggered by the financial crisis led to a distinctive recession in 2008 as well as turmoil in the financial markets. But even after significant reductions in short-term interest rates, central banks around the world were not in a position to fundamentally combat the effects of the financial crisis. With interest rates close to zero, central banks have lost their most important policy instrument. As a response, central banks around the world have implemented unprecedented monetary policy interventions, the so-called "unconventional monetary policy".

As far as the mere scope of the measures is concerned, the Fed has been so far the most active central bank. It has implemented several non-standardized monetary policy measures, in particular several rounds of Quantitative Easing (QE). The first round of QE was announced and launched in November 2008 with the primary objective of reducing the turbulence in the financial markets and stabilizing the US economy. After the completion of QE1 in March 2010, QE2 was launched in November 2010, followed by Operation Twist in September 2012 and an additional round of QE (QE3) in September 2012. Apart from the Fed, the BoE (2009-2014) and the BoJ (since 2010) also conducted extensive bond purchases to generate additional monetary impulses at the zero interest rate.

According to current empirical studies, the effects of massive bond purchases differ significantly between countries and regions. They depend on the timing, the state of the economy (uncertainties) and of the financial and capital markets as well as the framework conditions of the implementation. For the US, it appears that QE1 was most effective in influencing financial markets and macroeconomic variables such as unemployment and inflation. Regarding the effects on unemployment and inflation, QE2 is by far less effective and therefore not the focus of many studies (Belke et al., 2017).

While there have been noticeable differences ${ }^{1}$ between the QE rounds conducted by the FED and the central banks of other leading industrialized countries, a common aim of QE has been to put pressure on long-term yields. ${ }^{2}$ By reducing long-term yields, the FED expected to further stimulate economic activity and prevent significant declines in inflation rates. ${ }^{3}$ Furthermore, another mechanism of QE affecting the real economy runs via the exchange rate. However, long-term assets (and thereby interest rates) as well as exchange rates

\footnotetext{
${ }^{1}$ For a comparison of QE designs in the United States see Rosengren (2015) and Fawley and Neely (2013).

2 Apart from Operation Twist in the 1960s, the BoJ launched a purchase programme in March 2001. However, even the BoJ claimed that the policy has been largely ineffective.

${ }^{3}$ However, the impact on yields is not clear a priori. If QE strongly increased expectation about future inflation and growth, yields should actually increase.
} 
are often more affected by expectations about the future than by current economic conditions. Therefore, the announcement of programmes can have a stronger impact than the actual implementation. With respect to the impact of QE on the nominal exchange rate it is important to note that not each country can benefit from a nominal depreciation of their local currency, if several central banks start large-scale asset purchase programmes at the same time.

To measure the longer-term impact of $\mathrm{QE}$ on interest rates, interest rate relationships and exchange rates is inherently difficult, because one has to make many assumptions about how asset prices such as the exchange rate and the interest rate would have evolved in the absence of QE. ${ }^{4}$ Furthermore, there is evidence that the impact of $\mathrm{QE}$ crucially depends on the design of the programme, the economic environment and a country's economic structure. ${ }^{5}$

For example, in the case of Japan (long-term) interest rates had been very low for a long period and seemed little affected by the increasingly aggressive asset purchases of the BoJ starting in 2012. However, the yen started to depreciate strongly after the asset purchase programme was greatly increased in size and scope. By contrast, the effective dollar exchange rate moved little around the announcement and implementation dates of the different asset purchase programmes operated over the last seven years by the Federal Reserve. In the case of the UK, one actually observed a trend-wise appreciation of the pound over the period during which the Bank of England bought large amounts of gilts, and there was apparently some impact, albeit only temporary, on long-term interest rates (Gros et al., 2015).

However, the real difficulties go even deeper. The majority of available studies just looks at developments within the country undertaking $\mathrm{QE}$ and neglect the global environment. Global financial markets are highly integrated and (long-term) rates have been highly correlated across advanced economies, not only along a downwards trend, but also during cyclical ups and downs. Over most periods, rates have declined as much, sometimes more, in areas where QE was not undertaken. There is no sign that the fact that the ECB did not undertake bond purchases when they were undertaken by the US and the UK did in anyway prevent interest rates in the Euro area from following US rates downwards when only the US implemented QE (Gros et al., 2015).

According to the literature focusing on the national (but also international) transmission of QE shocks, authors generally pronounce two main transmission channels: the signaling channel and the portfolio balance channel. Although

\footnotetext{
${ }^{4}$ For the counterfactual analysis in macroeconometrics with an empirical application to Quantitative Easing see Pesaran and Smith (2012).

${ }^{5}$ See Rosengren (2015) for an assessment of how the design of the FED's QE programmes have affected their effectiveness. Fratzscher et al. (2013) for an empirical comparison of the effects of QE1 and QE2.
} 
both channels might explain a certain amount of the movements of financial variables in response to $\mathrm{QE}$, we believe that the global comparative evidence is also and probably even more compatible with the view that QE did not "move" interest rates, but appeared to be important because major central banks undertook purchases when they realized that the recession caused by the financial crisis would be longer and more severe than anticipated.

In this regard, it is also possible to explain the decline in interest rates before announcements of $Q E$ have been made by central banks. This observation might highlight that markets were quicker to revise their expectation and rates had thus come down before central banks started to buy assets. Therefore, market participants as well as central banks with their announcements of QE reacted to the same driving force - namely stronger adverse effects of the financial crisis than previously expected. In this regard, the prolonged weakness affected most of the developed world. Interest rates thus fell trendwise in most advanced economies independently of whether QE was implemented by the national central bank (Gros et al., 2015).

The view that the central banks programme as well as reductions in interest rates had a common underlying source is somehow compatible with one of the interpretation of the signal channel, if one assumes that QE generated new information about the (future) state of the (global) economy for market participants. Following this argument, QE has been a signal that the crisis would be longer and more severe. Market participants reduced their expectation about future growth putting downward pressure on interest rates. However, if one follows this interpretation the fall in interest rates might have occurred anyway at the latest when market participants would have revised their expectations about the severity of the crisis. ${ }^{6}$

Although several empirical studies credit QE with strong falls in US interest rates, rates fell as much in the Euro area, where QE was not undertaken (until recently). This finding might imply that several studies which neglect the global downward trend might give QE too much credit. The absence of a clear, distinct impact of QE episodes on interest rates and the exchange rate (e.g. the US), where QE was undertaken, should a priori have been puzzling. Although some (event) studies pronounce a very strong impact of QE on interest rates in the country where QE was implemented, international long-term interest rates remained to be highly correlated. Therefore, QE had little impact on interest rate differentials (USD versus euro). This aspect also explains why theses asset purchases had little impact on exchange rates. If QE had had such a strong impact on interest rates as often asserted (i.e. in the order of 100 basis points

\footnotetext{
${ }^{6}$ See Glick and Leduc (2011) for a similar interpretation.
} 
according to several event studies ${ }^{7}$ ), one should have expected a strong impact on the exchange rate.

As already indicated above, one new way to test the hypothesis that large scale asset purchases had a separate, identifiable impact on long-term interest rates (in the currency area where they are undertaken) for which the global downward trend in interest rates does not account is to estimate the cointegrated relationship between US and Euro area interest rates and to test whether one finds a structural break in this relationship around the time QE was undertaken in the US.

Apart from the hypothesis stated above, one has to admit that the overall effects of large asset purchase programmes are still not well understood - even based on a domestic perspective. In this regard, QE shocks might differ from conventional interest rate shocks in normal times not only with regard their relative magnitude, but also by changing relationships between economic variables. ${ }^{8}$ It has become a stylized fact in the theoretical and empirical literature that extraordinary and sustained macroeconomic policy actions can affect economic relationships and sometimes cause structural changes.

When the Federal Fund Rate reached the zero lower bound and the FED announced QE in November 2008, the FED effectively changed its monetary policy variable from the Federal Funds rate to its balance sheet size (Belke and Klose, 2013). In contrast to the pre-crisis era, it is now not possible anymore to measure monetary policy by simply looking at one interest rate. ${ }^{9}$ Motivated by this circumstance, several authors have argued in favor econometric models which incorporate possible structural changes. ${ }^{10}$ This aspect is further pronounced by Chen et al. (2013) which highlight that pre-crisis models could have become obsolete, as unconventional monetary policy might be transmitted in different ways from the conventional channels for interest rate in normal times. ${ }^{11}$

To summarise: until now, the overall effects of QE shocks have hardly been measured statistically accurately. Introduced as a direct response to the financial crisis, it appears extremely difficult to separate econometrically the effects of massive bond purchase programmes, the financial market situation and the macroeconomic environment. Secondly, the majority of estimation methods and empirical models are based on (too?) strong assumptions with regard to the

\footnotetext{
${ }^{7}$ See, for instance, Gagnon et al. (2011).

${ }^{8}$ Analyzing the link between the monetary base and the money supply (defined as M1, M2 or M3) from a national perspective, it appears that the relationship has been completely broken since 2008. See Gros et al. (2015) and McLeay et al. (2014).

${ }^{9}$ See the growing empirical literature which tries to measure the monetary policy stance by using "shadow rates". See, for instance, Lombardi and Zhu (2014).

${ }^{10}$ See Kapetanios et al. (2012) and Baumeister and Benati (2012).

${ }^{11}$ Gambacorta et al. (2014) argue in a similar fashion.
} 
transmission mechanisms of QE, apart from cointegration analysis (Belke et al., 2017). A change in the assumptions can have a strong impact on the results.

The listed aspects appear to be particularly relevant for a variety of so-called event studies which tend to find strong QE effects compared to other studies using alternative empirical methods. The strong assumptions about the identification of monetary policy shocks and the focus on very short time series are the two primary drawbacks of event studies. Therefore, the standard methodology of event studies does not provide a serious option to estimate the persistence of a monetary policy shock such as QE. For exactly this reason Belke et al. (2017) are relying on cointegration analysis in their study to test for the existence of common trends of different variables.

\section{QUANTITATIVE EASING - PREVIOUS EMPIRICAL FINDINGS}

While a large amount of empirical papers focus on domestic effects of QE, the empirical evidence on international effects of $Q E$ is still growing. In this section, we provide a survey of the literature which has attempted to quantify the effect of the FED's QE programmes. As our paper focuses on the effects of $\mathrm{QE}$ on interest rate relationships, the following literature review primarily focuses on impacts on financial markets - interest rates and the exchange rate.

Although this survey focuses on the QE programmes of the US Fed, the general impact of large-scale asset purchase programmes seems to vary considerably across countries or regions and also depends on the time and circumstances of their implementation. For the United States, it looks like QE1 was the most effective in influencing financial markets, unemployment and inflation, while QE2 was far less effective. As of today, the overall effects as well as the magnitude of such shocks are highly uncertain. Two main sources of uncertainty might explain large differences regarding the results of empirical estimations which try to estimate the impact of QE. Implemented as a direct response to the financial crisis, it appears to be extremely difficult to separate between effects of large-scale purchase programmes and financial markets as well as macroeconomic conditions. Secondly, the majority of estimation methods and models rely on strong assumptions (for instance, about the transmission mechanisms of QE). Changing the assumptions might heavily influence the results. In relation to this point, Rudebusch et al. (2007) show that although there is no structural relationship between the term premium and GDP, a reduced-form empirical analysis supports the existence of an inverse relationship between the term premium and real economic activity.

The aspects mentioned appear to be especially relevant for several event studies which tend to find very large effects of QE compared to studies using different empirical frameworks. The two main drawbacks of event studies are 
heavy assumptions about the identification of monetary policy shocks and the focus on a very short period of time. In this regard, the standard event study methodology does not provide an estimate of the persistence of a monetary policy shock (Wright, 2011). ${ }^{12}$

Although the aim of QE was to support the economic development as well as the performance of the labor markets in general, a large share of studies focus on its effect on long-term yields (especially Treasury bond yields). Regarding the effects of QE on domestic interest rates, the general consensus is that QE (especially QE1) had a diminishing effect on US medium and long-term yields.

Gagnon et al. (2011) investigate the effects of QE1 by using event study as well as time series methods. They find that the cumulative effect of LSAP announcements on yields of US treasury bonds as well as US agency debt declined up to 150 basis points. By scaling the FED purchases to '10-year equivalents', the authors measure the amount of duration which the FED removed from the market. Across the three asset classes which were purchased during QE1, the purchases account for more than $20 \%$ of the total outstanding 10 -year equivalents. Gagnon et al. (2011) argue that by reducing the net supply of assets with long duration, the programme appear to be successful in reducing the term premium which appears to be between 30 and 100 basis points. In accordance with their results, the authors highlight the importance of the portfolio balance channel relative to the signaling channel.

While Christensen and Rudebusch (2012) find similar cumulative reductions using an event study, their empirical results however stress the importance of the signaling channel. ${ }^{13}$ Wright (2011) generates interesting insights using a structural VAR with daily data to identify monetary policy shocks. While he finds significant effects on long-term yields, these effects die off quiet fast, with an estimated half-life of two month. These results might put the very large effects of event studies somehow into perspective.

Apart from event study methodology, further evidence is presented by Hamilton and $\mathrm{Wu}$ (2012) who use a term structure model to predict the effect of a change in the central bank's asset structure (short-for-long-term debt swap) and also indirectly the effect of buying $\$ 400$ billion in long-term treasuries. ${ }^{14}$ Their results are much lower compared to event studies mentioned, as they find that such a policy would cause a reduction of the ten-year rate of (only) 13 basis

\footnotetext{
${ }^{12}$ See Hamilton (2011) for several critical remarks on measuring the effects of QE by using event studies. Borio and Zabai (2016), Thornton (2013) and Deutsche Bundesbank (2016) provide surveys of event studies in the context of QE impact assessment.

${ }^{13}$ Further studies using event study methodology: Krishnamurthy and Vissing-Jorgensen (2011), D'Amico and King (2013).

${ }^{14}$ The purchase amount roughly corresponds to the amount of treasury bonds bought during QE1.
} 
points. Similar results have been obtained by Neely (2015a) and Meyer and Bomfim (2010). ${ }^{15}$

Chung et al. (2011) find effects of a magnitude which is not negligible. Based on counterfactual model simulations, they find that the past and projected expansion of the Federal Reserve's securities holdings since late 2008 are roughly equivalent to a 300 basis-point reduction in policy interest rates (since 2009 through 2012). Model simulations suggest that the additional stimulus provided by the purchases has kept the unemployment rate at a lower level $\left(1 \frac{1}{2}\right.$ percentage points by 2012) than what it would have been in the absence of the purchases and also argued that the asset purchases have probably prevented the US economy from falling into deflation.

Liu et al. (2014) find a smaller effect. By using a change-point VAR model, they estimated that the Fed's asset purchase programme reduced 10-year spreads by an average of 90 basis points over the crisis period. Without the asset purchase programme, the unemployment rate was estimated to have been 0.7 percentage points higher and inflation, on average, 1 percentage point lower in 2010.

Regarding the effects on international financial markets, the majority of paper find cross-border effects as well as effects on the exchange rate. Fratzscher et al. (2013) examine the international effects of QE1 and QE2. They find that QE1 was effective in lowering sovereign yields and raising equity markets in the US and abroad. According to their results, QE1 might have generated a safe haven effect / strong global rebalancing of portfolios out of emerging markets and into US equity and funds and thereby putting upward pressure on the USA. However, regarding the effects of QE2, the authors find that this programme has overall been ineffective in lowering yields worldwide and has caused sizeable capital outflows, mainly into EME, and thereby marked a USD depreciation.

Neely (2010, 2015b) puts more weight on the effects of QE on treasury yields of developed countries.16 Using an event study as well as a portfolio balance model, Neely (2010, 2015b) finds substantial evidence that QE1 announcements have reduced sovereign yields in the US and abroad. Furthermore, Neely (2010, 2015b) delivers significant evidence that QE has generated a general depreciation of the USD. Bauer and Neely (2014) employ dynamic term structure models to uncover whether international yields have declined as a result of signaling or portfolio balance effects. They find that the relative importance of the signaling channel increases with an economy's sensitivity to signals from conventional US monetary policy. Consistent with the notion that Canada is highly sensitive to US monetary policy, the authors are able to identify large signaling effects for

\footnotetext{
${ }^{15}$ For further evidence, see Krishnamurthy and Vissing-Jorgensen (2011).

${ }^{16}$ Neely uses data for the US, Australia, Germany, Japan and the UK.
} 
Canadian treasury yields. For Australian and German treasury bonds, the authors find especially large portfolio balance effects.

\section{FISCAL POLICY, DEBT MANAGEMENT AND THE PORTFOLIO BALANCE CHANNEL}

Before we turn to the main analysis of this paper, we would like to discuss one additional aspect which is closely related to the effectiveness of QE, fiscal debt management.

Regarding the main channel of transmission, several academics as well as officials have - as already mentioned above - highlighted the importance of the portfolio balance channel. ${ }^{17}$ This transmission channel is based on the preferred habitat/imperfect asset substitutability theory and predicts that a reduction in the net supply of a given asset should in fact reduce its term premia and thereby its yield (D’Amico and King, 2012). In this regard, if the central bank buys large amounts of long-term (treasury) assets, the central banks shortens the maturity structure of debt instruments that private investors have to hold, changing the relative net supplies and thereby reduces long-term interest rates. Empirical as well as theoretical papers mainly find evidence that the portfolio balance channel works

However, the theoretical approach assumes that the (fiscal) debt management is exogenous and that it does not respond measures taken by the central bank and therefore does not change its behavior. Greenwood et al. (2014) analyses the debt management of the US treasury during the QE rounds and highlights that the fiscal side tended to supply the markets with longer maturity than during normal times / before the crisis. Regarding the supply of long-term government debt, the authors show that the amount of government debt with a maturity over 5 years held by the public (excluding the FED's holding) has actually risen from 8 percent of GDP in 2007 to 15 percent in 2014. Focusing on the volume of 10-year duration equivalent debt, the stock has actually doubled from 13 percent of GDP to 26 percent over the same interval. Despite massive asset-purchase programmes by the FED, the pressure to absorb (long-term) government debt has increased rather than decreased since the beginning of the crisis.

In this regard, the central bank and the fiscal side have been pushing in opposite directions with debt management policies at least partly offsetting the impact of monetary policy. Analyzing the reasons, Greenwood et al. (2014) find that roughly two thirds of the increased supply of long-term treasury debt can be related to the tremendous increase in outstanding debt due to large deficits in the recent years, while the remaining one-third is due to the Treasury's active policy of extending the average maturity of government debt. The net result of

${ }^{17}$ See Bernanke (2012). 
these two opposing policies has overall been still a substantial increase in the longer-term securities held by the public: the fiscal deficits combined with the lengthening of maturity by the debt management office would have increased the supply (measured in the equivalent of 10- year bonds) by close to $30 \%$ of GDP. But the various rounds of asset purchases by the Federal Reserve took about 15\% of GDP from the market. Therefore, about one-half of this increase in longer-dated US federal securities has been undone by the various rounds of asset purchases of the Federal Reserve, which was needed to lower (long-term) interest rates.

Greenwood et al. (2014) also document that the weighted-average duration of federal debt securities issued by the Treasury has increased from about 4 years in 2008 to 4.6 years in late 2014. However, if one aggregates the Treasury and the Federal Reserve, the (weighted-average) duration has actually fallen to 2.9 years (Greenwood et al., 2014, p. 11) - a reduction of 1.7 years. This lower effective average maturity of the US public (federal) debt might now become relevant as the Federal Reserve is about to start increasing rates. The increase in rates will lead to a higher cost of debt service more quickly than if the duration of the public debt had been at the 4.6 years, which apparently was the target of the Treasury since 2008.

Greenwood et al. (2014) conclude that the common impression that the FED asset purchases reduce long-term interest rates through the portfolio balance effect might be wrong, as "the totality of policy has raised rather than reduced the quantity of long-term government debt held by private investors.” In this regard, it is argued that the fiscal sector's policy reaction has crowded out the portfolio balance effects of QE which should have theoretically been the case.

\section{INVOLVEMENT OF THE GLOBAL ENVIRONMENT: SUCCESSFUL QE AS A STRUCTURAL BREAK IN INTERNATIONAL INTEREST RATE RELATIONSHIPS}

As said, the problems with the estimation of QE effects are large. The majority of academic studies consider only developments within the country that implemented QE and neglect the global environment. However, global financial markets are strongly integrated and the (long-term) interest rates of developed economies are highly correlated not only during their downward trend that has lasted for almost a quarter of a century but also during their cyclical upward and downward movements (see Figure 1). In the past, even the interest rates in countries that did not perform QE during the period under consideration decreased by more. This is the case, for example, in the period just before the start of the ECB-QE for the Eurozone, whose long-term interest rates is approximated by the German 10-year interest rate. These considerations suggest 
that a number of studies that neglect the global downward trend describe QE as having too big effects on long-term US interest rates.

Figure 1

Long-term interest rates in important currency areas since 1990

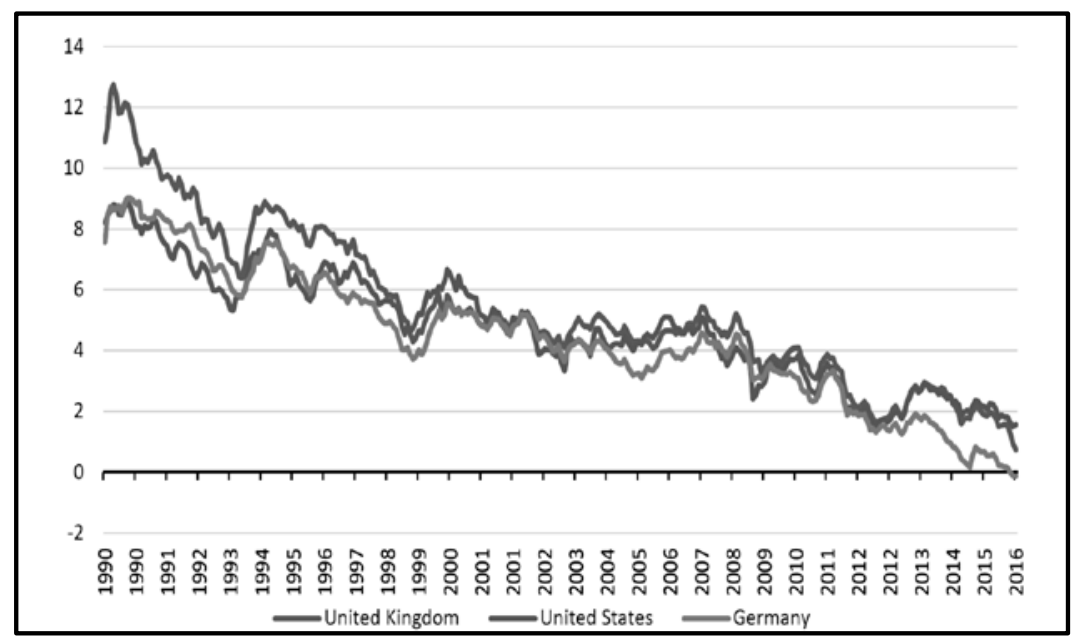

Source: OECD and Belke et al. (2017).

\section{EFFECTS OF THE US QE ON INTEREST RATES, EXCHANGE RATES AND INFLATION - STRUCTURAL BREAKS IN THE COINTEGRATED VAR MODEL}

The aim of large-scale asset purchases from central banks is to reduce longterm interest rates. Given the fact that interest rates had already reached the zero lower bound in the short run, this corresponded to the goal of flattening the yield curve. In addition, QE may also work through rising inflation expectations and result in falling real interest rates. Regarding the impact of QE on the nominal exchange rate, it should be noted that not all QE-active countries can benefit from a nominal depreciation of their domestic currency if several central banks start large-scale asset purchases at the same time.

Belke et al. (2017) evaluate the effectiveness of QE by testing the common trend of international long-term interest rates with state-of-the-art structure break tests (log likelihood tests, chow tests, recursive tests) for a structural break at the time of the announcement or implementation of QE1. If QE1 were successful, US interest rates would be lower than the remaining interest rates by a certain amount from the date in question. However, at the same time it would continue to trend with international interest rates. 
For this purpose, Belke et al. (2017) use the cointegration approach to analyse whether the Fed's QE1, which started in 2008 and lasted until 2013, triggered a structural break in the US-European interest rate relationship. In other words, they are isolating the effect of the QE1 programme on US interest rates by asking about the interest rate reducing effect in addition to the common trend with the euro interest rate. According to Taylor (2016), their study is one of the first to test whether $\mathrm{QE}$ has changed the relationships on international financial markets.

Another rare example is Thornton (2014a), who did this by looking at the effect of QE on the difference between the US 10-year Treasury yields and the 10-year sovereign yields for Germany, France and the UK. Thornton argued that if QE affected US long-term rates, the spread between the sovereign yields of countries that did not engage in QE and those in the US would have increased significantly and persistently following the Fed's first QE announcement in November 2008. He showed that the spreads actually declined, that is, foreign yields fell relative to the US yield. Thornton tested for a structural break in the relationship using the Bai-Perron test. He found no statistically significant break for either Germany or the UK, but did find a statistically significant break for France, which occurred later and coincided with the European financial crisis. He noted that the results could be affected by differentials in these economies' inflation and output performance, so he repeated the test using real rate differentials and found qualitatively similar results. He also showed that these countries did not have significantly poorer economic growth and concluded that QE had no effect on US long-term rates.

In order to implement the respective research strategy, interest rates for the USA and the Eurozone should be selected first. The decision for the US is clearcut, "treasury bond yields" are the usual choice. They are generally regarded as a benchmark for domestic interest rates. For the Eurozone, we use the yield on German government bonds. This is justified by the fact that German government bonds can be seen as the bonds in the Eurozone with the lowest risk. This is to avoid distortions of the estimated cointegration equations that can be generated by rising risk premia on government bonds of other Euro area member countries in the high phase of the European debt and banking crisis. For both regions, Belke et al. (2017) use the return on 10-year government bonds. In addition, they are implementing the nominal exchange rate (USD / Euro) into our cointegrated VAR model. They employ monthly data for the estimation period from January 2002 to December 2014 in order to also grasp the dynamics to a sufficient extent.

\section{EMPIRICAL RESULTS}

Belke et al. (2017) find empirically that the Fed's massive bond purchases do not "disturb" the "co-movements" of US and Euro interest rates. They also 
conclude that, instead of QE1, the debt and banking crisis in the Eurozone has triggered a structural break. Therefore, the latter had a more destabilizing influence on the transatlantic interest rate differential than QE1.

Robustness tests show that this unambiguous result is not due to too little "power" of the structural break tests used. To show this, Belke et al. (2017) also repeat their test procedure with alternative ("counterfactual") paths for US longterm interest rates. They find that their test method would have detected a structural break if US long-term interest rates had been lower by 25 to 50 basis points after the announcement of QE1. Thus, their procedure would have had reported the slightest influence of QE1 on the transatlantic interest rate differential.

As an additional robustness test, the authors estimate vector autoregressions (VARs) that take into account macroeconomic feedback between long-term interest rates, exchange rates, inflation and growth in the tradition of Thornton (2014b). Their VAR results again confirm the above findings: there is no evidence of structural breaks in the long-term relationship between international long-term interest rates at the time of QE1.

Their result is compatible with the implications of the signaling channel. QE1 was thus either interpreted as a sign that the crisis could be longer and more severe than initially expected. The market participants accordingly reduced their expectations about future growth, which put downward pressure on interest rates. Hence, the fall in interest rates would have taken place anyway, due to a revision of market expectations. Or the markets had already revised their expectations and the interest rates had thus already fallen before the central banks began to buy bonds at all. From this point of view market participants and central banks with their announcements of QE responded to the same trigger - namely stronger than previously expected effects of the financial crisis. In this regard, the ongoing economic weakness has affected most of the developed world. Interest rates therefore fell in most advanced economies, regardless of whether QE was actually implemented by the national central bank or not. As a result, QE had only little effect on interest rate differentials (USD versus Euro).

The small effect on the transatlantic interest rate differential also explains why the bond purchases just had little effect on exchange rates. If QE had such a large impact on interest rates as often claimed (event studies are of the order of 100 basis points), a strong and clear impact on the exchange rate could have been expected - a consistent depreciation of the US dollar. However, Belke et al. (2017) show in their study that phases of QE in the US were interrelated with an appreciation and a depreciation of the US dollar.

Otherwise, their result either means that QE has been ineffective, or that QE has turned out to be super-effective, since it simultaneously pushed down longterm interest rates worldwide (perfect "spillover"). But then, according to 
interest rate theory, the influence of QE1 on the dollar exchange rate should be zero. The claim that the US started a "currency war" via implementing QE1 would, however, not be tenable in that case.

It cannot be a perfect "spillover" in our findings, as the QE of the Federal Reserve only reduces the supply of US government bonds. The hypothetical super-effectiveness of QE1 is not compatible with the portfolio balance approach, which is commonly used to justify the effectiveness of QE. Because the supply of (and probably the demand for) euro-denominated sovereign debt is hardly affected by the US QE1, there is no reason to believe that the US QE has a nearly equal impact on the long-term interest rates of the Eurozone as on US interest rates because the largest investors are usually forced to invest in their home currency. Governments, as well as most private households, rarely diversify their portfolios internationally (Belke et al., 2017).

The effectiveness of large-scale asset purchases by the Fed should therefore not be simply measured by the reduction of US interest rates, but by the reduction in interest rate differentials as between the US and the Eurozone (or other major markets). The fact that extensive asset purchases by the Fed did not have a "differential impact" on the US is no surprise with regard to the above argument.

\section{GLOBAL LIQUIDITY SPILLOVER}

The literature about the determinants of global interest rates assumes that all relevant national capital markets are linked by the global capital market, so that the interest rate is the same everywhere. Accepting this hypothesis, national central banks such as the Fed (and also the ECB) cannot influence bond yields in their own jurisdictions. Because any slight change in a national interest rate would attract such large inflows of monetary and financial liquidity that any initial interest rate differential would quickly disappear ("global liquidity", "global spillovers"). In the case of fully integrated global capital markets, national monetary policy can no longer be expected to have a systematic impact on domestic bond yields. The empirical evidence delivered by Belke et al. (2017) supports this view. Further activation of the ECB, for example by expanding its bond purchase programme, is likely to be largely ineffective. At least, one would have to simultaneously estimate a two-equation system with one equation modelling the "QE reaction function" including the drivers of $\mathrm{QE}$ activation as right-hand-side variables and the other equation specifying the effects of QE. This is, however, left to future research.

The fact that studies such as Belke et al. (2017) do not find an independent, separate effect of the American QE on the US economy, which is not related to the global downward trend of interest rates, suggests that current studies significantly overestimate the impact of QE. 


\section{SUMMARY AND OUTLOOK}

This article examined the efficiency of unconventional monetary policy using the example of the US bond purchase programme QE1. The use of recursive estimation methods does not reveal any significant signs of a structural break caused by QE1. Moreover, event studies that tend to find QE effects appear to be far less suitable for the analysis of the effects of QE due to theoretical reasons than approaches based on cointegration methods.

We conclude that there is no evidence that QE has an impact on US interest rates that cannot be explained by the global downward trend of long-term interest rates which already lasts for a quarter of a century. While Belke et al. (2017) have to reject empirically that QE1 had an impact on the transatlantic interest rate, they find evidence that the start of the European debt crisis had a much greater impact on generating instabilities of the cointegrating global interest rate relationship. As a result, the effect of the QE1 programme remains far below expectations.

This negative finding regarding the intended interest-rate effects of the USAmerican QE programme is a source of concern with an eye on the considerable negative side-effects of the US-QE programme. Finally, the observation that QE did not affect the transatlantic interest differentials makes it very difficult to maintain that the US QE is part of a currency war because it led to a depreciation of the US dollar.

The conclusion by Belke et al. (2017) that the US QE1 programme has not affected the transatlantic interest rate "co-movement" is, as previously indicated, consistent with the view that QE was triggered by the reaction of leading central banks to negative shocks of global inflation and / or demand. These shocks could be quite global in nature. This is suggested by recent empirical studies that show that inflation has a significant global component. But even if the shocks were nationally caused (for example, deflationary forces in the eurozone could be more widespread than in the US), their impact on long-term interest rates in different major economies could be uniform because long-term demand shocks in any major economy are likely to spread across the world economy.

Based on a preliminary presentation of the paper by Belke et al. (2017) at the Conference on Macroeconomic Analysis and International Finance in Crete, Taylor (2016) concludes that the finding by Belke et al. (2017) also raises doubts about some of the rationales for the effect of QE, including portfolio balance arguments, which would not be expected to have such large global effects. To be sure, it could be that QE1 had the signaling effect that short-term policy rates in the US would be lower for longer, and thereby signaled the same for the ECB policy rate assuming some kind of policy contagion. If so, term structure models might suggest co-movements in long-term rates in Europe. He adds: "Their model also includes the exchange rate, which will enable them or 
others to use the approach to examine exchange rate effects in other periods and countries, and perhaps estimate the effect of QE by the BoJ and the ECB in 2012-2015, which eyeball econometrics suggest led to depreciation of the yen and then the euro". We leave this interesting issue for further research.

\section{BIBLIOGRAPHY REFERENCES}

BAUER, M.D. and C.J. NEELY (2014). "International channels of the Fed's unconventional monetary policy". Journal of International Money and Finance, Vol. 44, pp. 24-46.

BAUMEISTER, C. and L. BENATI (2012). "Macroeconomic effects of a spread compression at the zero lower bound". Bank of Canada Working Paper, 2012-12.

BELKE, A., D. GROS and T. OSOWSKI (2017). "The effectiveness of the Fed's Quantitative Easing policy: New evidence based on interest rate differentials". Journal of International Money and Finance, Vol. 73, pp. 335-349.

BELKE, A. and J. KLOSE (2013). "Modifying Taylor reaction functions in presence of the zero-lower-bound - Evidence for the ECB and the Federal Reserve". Economic Modelling, Vol. 35, pp. 515-527.

BERNANKE, B. (2012). "Monetary Policy since the onset of the crisis". Presented at the Federal Reserve Bank of Kansas City Economic Symposium, Jackson Hole, Wyoming, 31 August.

BORIO, C. and A. ZABAI (2016). "Unconventional monetary policies: a re-appraisal". BIS Working Paper No. 570, Bank for International Settlements, Basle.

CHEN Q., A. FILARDO, D. HE and F. ZHU (2013). "International spillovers of central bank balance sheet policies". BIS Working Paper No. 66, Bank for International Settlements, Basle.

CHRISTENSEN, J. and G. RUDEBUSCH (2012). "The response of interest rates to US and UK Quantitative Easing". Economic Journal, Vol. 122(564), pp. F385-F414.

CHUNG, H., J.-P. LAFORTE, D. REIFSCHNEIDER and J.C. WILLIAMS (2012). "Have we underestimated the likelihood and severity of zero lower bound events?". Journal of Money, Credit and Banking, Vol. 44(1), pp. 47-82.

D'AMICO, S. and T.B. KING (2013). "Flow and stock effects of large-scale Treasury purchases: Evidence on the importance of local supply". Journal of Financial Economics, Vol. 108(2), pp. 425-448.

DEUTSCHE BUNDESBANK (2016). "The macroeconomic impact of Quantitative Easing in the Euro area". Monthly Reports, June, Frankfurt/Main.

FAWLEY, B. and C. NEELY (2013). "Four stories of Quantitative Easing". Federal Reserve Bank of St. Louis Review, Vol. 95(1), pp. 51-88.

FRATZSCHER, M., M. LO DUCA and R. STRAUB (2013). "On the international spillovers of US Quantitative Easing, Discussion Papers". DIW Berlin, No. 1304, German Institute for Economic Research, Berlin.

GAGNON, J., M. RASKIN, J. REMACHE and B. SACK (2011). "The financial market effects of the Federal Reserve's large-scale asset purchases". International Journal of Central Banking, Vol. 7(1), pp. 3-43. 
GAMBACORTA, L., B. HOFMANN and G. PEERSMAN (2014). "The effectiveness of unconventional monetary policy at the zero lower bound: a cross-country analysis". Journal of Money, Credit, Banking, Vol.46, pp. 615-642.

GLICK, R. and S. LEDUC (2013), "Central bank announcements of asset purchases and the impact on global financial and commodity markets". Journal of International Money and Finance, Vol. 31(8), pp. 2078-2101.

GREENWOOD, R., S.G. HANSON, J.S. RUDOLPH and L.H. SUMMERS. (2014). "Government debt management at the zero lower bound". Hutchins Center on Fiscal \& Monetary Policy, Working Paper No. 5, Brookings.

GROS, D., C. ALDICl and W.P. DE GROEN (2015), "Lessons from Quantitative Easing: Much ado about so little?". CEPS Policy Brief No. 330, Centre for European Policy Studies, Brussels.

HAMILTON, J.D. (2011). "Evaluating Quantitative Easing using event studies" (http://econbrowser.com/archives/2011/07/evaluating_quan).

HAMILTON, J.D. and J.C. WU (2012). "The effectiveness of alternative monetary policy tools in a zero lower bound environment". Journal of Money, Credit and Banking, Vol. 44(1), pp. 3-46.

KAPETANIOS, G., H. MUMTAZ, I. STEVENS and K. THEODORIDIS (2012). "Assessing the economy-wide effects of Quantitative Easing". Bank of England Working Paper No. 443, London.

KRISHNAMURTHY, A. and A. VISSING-JORGENSEN (2011). "The effects of Quantitative Easing on interest rates: channels and implications for policy". National Bureau of Economic Research Working Paper No. 17555, Cambridge, MA.

LIU, P., H. MUMTAZ, K. THEODORIDIS and F. ZANETTI (2014). "Changing macroeconomic dynamics at the zero lower bound". Bank of England, London, mimeo.

LOMBARDI, M. and F. ZHU (2014). "A shadow policy rate to calibrate US monetary policy at the zero lower bound". BIS Working Paper No. 452, Bank for International Settlements, Basle.

MCLEAY, M., A. RADIA and R. THOMAS (2014). "Money creation in the modern economy". Bank of England Quarterly Bulletin, 2014/1, London, pp. 1-14.

NEELY, C.J. (2010). "The large-scale asset purchases had large international effects". Federal Reserve Bank of St. Louis Working Paper 2010-018G, St. Louis, July.

NEELY, C.J. (2015a). "How persistent are unconventional monetary policy effects?". Federal Reserve Bank of St. Louis Working Paper 2014-004B, July, update.

NEELY, C.J. (2015b), "Unconventional monetary policy had large international effects". Journal of Banking and Finance, Vol. 52, pp. 101-111.

PESARAN, H.M. and R. SMITH (2012). "Counterfactual analysis in macroeconometrics: an empirical investigation into the effects of Quantitative Easing". Institute for the Study of Labor, Bonn.

ROSENGREN, E.S. (2015). "Lessons from the U.S. Experience with Quantitative Easing". President \& Chief Executive Officer Federal Reserve Bank of Boston, The Peterson Institute for International Economics and Moody's Investors Service's 8th Joint Event on Sovereign Risk and Macroeconomics, Frankfurt, Germany, February.

RUDEBUSCH, G.D., B.P. SACK and E.T. SWANSON (2007). "Macroeconomic implications of changes in the term premium". Federal Reserve Bank of St. Louis Review, Vol. 89(4), pp. 241-269. 
TAYLOR, J.B. (2016). "Discussion of Belke, Gros and Osowki (2017): New test finds no impact of QE on long-term interest rate". Web: https://economicsone.com/2016/05/ 28/new-test-finds-no-impact-of-qe-on-long-term-interest-rate/.

THORNTON, D.L. (2013). "An evaluation of event-study evidence on the effectiveness of the FOMC's LSAP program: Are the announcement effects identified?". Federal Reserve Bank of St. Louis Working Paper No. 2013-033A, October.

THORNTON, D.L. (2014a). "Has QE Been Effective?". Federal Reserve Bank of St. Louis Economic Synopses, No. 3.

THORNTON, D.L. (2014b). "QE: Is There a Portfolio Balance Effect?". Federal Reserve Bank of St. Louis Review, Vol. 96(1), pp. 55-72.

WRIGHT, J.H. (2012). "What does monetary policy do to long-term interest rates at the zero lower bound?". Economic Journal, Vol. 122(564), pp. F447-F466. 